\title{
Sciendo
}

Administration, vol. 69, no. 3 (2021), pp. 19-43

doi: 10.2478/admin-2021-0019

\section{From the community handywomen to frontline heroes: Charting a century of Irish nursing and midwifery regulation}

\author{
Denis Murphy \\ Association for Dental Education in Europe; Dublin Dental University \\ Hospital, Trinity College Dublin, Ireland \\ Kim Gilligan \\ Faculty of Education and Society, University of Sunderland, UK

\section{Derek Watson} \\ Faculty of Business, Law and Tourism, University of Sunderland, UK
}

\begin{abstract}
This paper argues that professional regulatory frameworks are shaped by sociocultural factors and prevailing ideologies that stem from society's interactions with and expectations of the regulated professions. Taking a century of Irish nursing and midwifery regulation as a case reflection, the paper highlights five regulatory pivot points to provide a historical narrative of how adopting a sociocultural perspective can enlighten our understanding of the current regulatory form. A form that in early twenty-first-century Ireland resulted in the establishment of a professionally contentious, non-professional (lay) majority on the regulatory board for these frontline professions. The paper concludes by suggesting that when viewed through a sociocultural lens,
\end{abstract}


regulatory change is to be expected. As prevailing ideologies change, power, influence and cultures alter to support and reinforce the new ideology. Professional regulation thereby becomes reflective of society's views on professionalism and professional identity, drawing on society's historical experiences of the professions.

Keywords: Professional regulation, nursing and midwifery, Ireland, sociocultural perspective, ideology

\section{Introduction}

Regulation of the professions of midwifery and nursing celebrated 100 years in Ireland during 2018 and 2019, respectively. This landmark occasion was marked by the regulator hosting two celebratory conferences to showcase the professions. While the evolution of the regulation of nurses and midwives was not the core theme of these conferences, the programme included a recounting of the regulatory history of the two professions. Drawing on conference presentations, published works and an exploration of the legislative Acts, along with publicly available consultations around them, this paper aims to summarise and document the changing face of Irish regulation over the century for these professions. The resulting historical narrative uncovers professional regulatory forms or frameworks shaped by wider sociocultural factors and ideological understandings of power and governability (Foucault, 1991). The paper makes a case for the charting of changing regulatory frames as ideological reflections of temporal and changing societal norms and expectations of the professions. Over the century these sequential ideologies led to the creation of different regulatory frameworks, culminating in the 2011 Nurses and Midwives Act's focus on a non-professional majority, colloquially known as the 'lay majority' board.

To demonstrate the progressive nature of regulation, the paper draws on five pivotal points in the timeline of nursing and midwifery regulation to highlight the impact that ideological understandings and sociocultural norms had on the direction and focus of Irish regulation for these professions. The five historical points given focus are:

1. the late nineteenth-century reshaping of nursing and midwifery identities;

2. early registration attempts, resulting in the 1918 Midwives (Ireland) Act and 1919 Nurses' Registration (Ireland) Act; 
3. post-World War II era's wider healthcare reform and the 1950 Nurses Act;

4. embedding professional self-regulation within the 1985 Nurses Act;

5. healthcare scandals and calls for transparency, leading to the 2011 Nurses and Midwives Act.

The paper commences with a brief discussion on sociocultural theory, uncovering how diverse aspects influence social understandings of concepts of power, identity and, in the context of this paper, professionalism. In addition, historical, social and legislative links between Ireland and the UK that led to complex and, at times, volatile political relationships are explored, as these played a role in shaping the professions and their regulation to present times.

The paper concludes that taking a sociocultural view clarifies our understanding of our current context as resulting from our historical, political and wider sociocultural frames at an individual, professional and societal level. Over time, through the public's experiences and engagement with the community of regulated nurses and midwives, Irish society evolved its understanding of concepts such as professionalism and professional identity as associated with these professions. This in turn has led to an evolving reframing of the professions' regulatory form and framework.

\section{Sociocultural theory: Experience of practice influencing perspectives on professionalism}

Advocates of sociocultural theory believe our engagement, interaction, interpretation and internalisation of societal history, structures and cultures shape our identity as individuals, as members of society and of communities within it. For socioculturalists, we are engaged in a constant renegotiation of our identity within our wider sociocultural and historical context, its norms and expectations. This in turn influences our views on meaning and sense making (Vygotsky, 1978; Wertsch, 2008), learning (Lave, 1998; Lave \& Wenger, 1991), identity (Rogoff, 2008) and, at a professional level, concepts such as professional practice and professionalism (Khalili et al., 2014; Wenger, 1998).

Adopting a sociocultural view acknowledges a myriad of concepts within its framework. Concepts such as identity, gender and gendered roles, feminism, politics, societal structures, globalisation and our lived 
sociocultural history are just some of the elements that can feature within a socioculturalist's frame. A core element of sociocultural theory is the influence that 'situatedness' within context and practice (Lave \& Wenger, 1991, p. 31) has on 'mediating' meaning and the shaping of our identity (Wertsch, 2008), be it societal, professional or personal. It is through participation in practice and engagement with the reifications (the symbols, structures and tangibles) of communities that we learn and thereby become a member of a particular professional community of practice within society (Wenger, 1998).

To socioculturalists, professionalism and professional identity are considered continually evolving time-based constructs grounded in society's understanding of the professions. Evans (2008, p. 33) refers to professionalism as 'professionality-influenced practice' of a particular profession that 'contributes to and reflects perceptions of the profession's purpose and status'. The Professional Standards Authority (2016, p. 20), the regulator of professional regulators in the UK, concludes that professional identity is 'fluid and dependent on individuals' own subjective interpretations'. Professional identity and the related concept of professionalism are thus enacted in practice, and reflective of the diversity of how they are experienced by society and the professions. This fluidness can be likened to what Foucault (1966) terms an ideology, episteme or world view. Ideology, Foucault (1966, p. 74) suggests, is the 'foundation and philosophical justification' that dictates order, embeds, and reinforces power, knowledge and structure within a society. An example of how ideological change can influence concepts such as professionalism is offered by Khalili et al.'s (2014) discussions of the pre-1950s normative value systems with an ideological emphasis on conformity, power, hierarchy and control. According to Khalili et al. (2014), this ideology has fallen out of favour because it is misaligned with the predominantly inter-professional, global and diverse ideology that was in vogue at the turn of the twenty-first century.

As society changes, so too do our definitions of professionalism and in turn what people expect from their experiences with professionals. These changes also alter what it means to identify as a member of a specific profession. In sociocultural terms, the realities we experience as a member of society or as a member of a particular profession within it are what Wenger (1998, pp. 149-55) terms 'temporal', influenced by history, society and our participation or experience within it. In adopting such a sociocultural perspective, the concept of professional regulation can be viewed as a temporal construct 
influenced by the prevailing ideology and historical societal experiences of the professions being regulated. As ideology changes, the approach to regulation, along with its primary driving force and focus, also alters to reflect the new prevailing ideology and its direction. The premise of this argument is that professional regulation becomes a symbolic reflection of the political and societal system to enable or indeed hinder professional practice in a particular profession. Drawing on recent historical experiences of wider social, political and cultural beliefs about professional identity and of the professions, a reshaping of professional regulation and the symbols and structures that support it occurs. The following provides some examples from a centenary of nursing and midwifery regulation in Ireland to unpack the discussion further.

\section{Prevailing ideology: The role of history, politics, religion and gender in influencing change}

Looking back on Ireland of the late 1800s and early 1900s, a vastly different country, citizen and ideology was at play in comparison to what we have today. British imperialism/colonialism, the 1801 Act of Union and the 1838 Poor Law were some of the drivers reinforcing a shared and volatile history between Britain and Ireland (Geary, 2018; Mohr, 2010; White, 2010). The ideology behind these enabled and enacted a power and social construct aimed at enforcing law and order over what the ruling classes of the time viewed as British subjects. Constructs around landownership (Walsh \& Fox-O'Mahony, 2018), access to education (Lougheed, 2018), as well as views on religion (White, 2010) and gender (Gray \& Ryan, 1998), all played a part in controlling society and shaping identity within Ireland. Toward the end of the nineteenth century, there was an increasing desire and drive towards Irish nationalism. This led to a shift in Irish ideology and the creation of a new 'Irish-ness' (Clarke, 2015). This new Irish ideology remained a male-dominant society, with a stronger Catholic ethos. Rebelling against the status quo to create the new Irish-ness, genderspecific roles were again being reinforced within Irish identity (Clarke, 2015; White, 2010). Within society, laws were changing and norms evolving to reflect a new ideology. Fletcher's (2001) discussion on Ireland's evolving abortion laws at the time is a useful example. Fletcher explores how the evolving Irish identity was fighting against the existing ideology. In aiming to overturn existing colonial views, a strong pro-life, Catholic stance evolved in Ireland. Thus, for Fletcher, 
creating the new national Irish identity involved reinforcing or confronting existing views on gender, religion, ethics and class.

In a similar vein both Fahey (1998) and Sheehan et al. (2017) recount how the male-dominated, class-structured, Catholic ethos and ideology would continue to be embedded within legislation right up to the 1970s. Examples cited by Sheehan et al. (2017) include a 1932 'marriage bar' stopping married women from working in the civil service, and the enshrining of the concept of motherhood as the 'natural' role for women within Article 41.2.1 of the Irish Constitution. These are examples of what Ó Drisceoil (2020, p. 3) views as 'political interventionism and assertiveness' by the Church, aimed at embedding Catholic norms within the new Irish society of the time. In doing so, ideology was being embedded within our laws that would reinforce the role of the Church within the state. The new Irish-ness would go on to influence the direction of Irish society and culture for over a century. From the perspective of this paper, this time of ideological change also included a change in attitudes and expectations of healthcare. Geary (2018, p.20) identifies that in late-1800s Ireland ideological change in healthcare was shifting from a 'Victorian emphasis on individualism and self-help' to a more socially accountable state taking responsibility to prevent 'pauperism'.

The nursing and midwifery professions we know today were in the early stages of professional development and organisation. However, there were a growing number of hospitals giving structure to Irish healthcare, employing the predecessors to regulated nurses and midwives. Nurses were now working in the community setting as district nurses and in poorhouses and a growing number of hospitals (Robins, 2000). For the most part, these institutions focused on care of the poor and were of a religious, charitable or philanthropic nature (Fealy, 2006). Midwifery was primarily community based, provided by the Irish 'handywomen' (predecessors to the formally trained and regulated midwife in Ireland) (Breathnach, 2016). Breathnach (2016, p. 36) uncovers 'political, socioeconomic and cultural reasons' at play at the time when it came to views on traditional and women's medicine - views where some recount the handywomen as being 'complicit in concealing pregnancy' and as 'unprofessional drunkards' while others show them as central respected members of the local community (Breathnach, 2016, p. 39). Breathnach's 2016 work draws on the Irish Folklore Commission and helps to expose elements of the prevailing ideology at play within Ireland, an ideology where midwifery and nursing was women's work and issues such as gender, class, religion 
and cultural beliefs were very much at play. Within the ideology of the time, the profession of nursing became socially constructed as something that was profane (McNamara, 2008) and the district or 'outdoor' nurse viewed as 'a protégée of the local gentry' (Robins, 2000 , p. 12). Such views demonstrate how the male-dominated society was shaping what was acceptable for a woman to do and to be. Within medicine, there was strong opposition to women practitioners until the UK General Medical Council began accepting registration towards the end of the 1800s (Hughes, 2018).

Authors such as Fealy \& O'Doherty (2005), Clarke (2015), Breathnach (2016), O'Connell (2018), and Glasper \& Carpenter (2019) highlight that wider social, political, historical and cultural views were indeed influencing and impacting the direction of the evolution of the nursing and midwifery professions and their identity in Ireland in the late nineteenth century. Regulatory beginnings for nurses and midwives in Ireland are rooted in the ideology outlined above. An ideology best summarised as created by British-Irish political volatility: a male-dominant, poverty-stricken and Catholicethos Irish society. An ideology attempting to assert political selfdominance against the British Empire.

\section{Regulatory beginnings: The 1918 and 1919 Acts}

At the turn of the twentieth century, the professions were reinforced as women's work and painted as disorganised subordinate roles to their male medical counterparts. Nurses and midwives, particularly those working outside the growing hospital network, were viewed as individuals who needed supervision and control so as to protect society (Geary, 2018). Nursing was concerned with taking care of the 'sick poor' and, by being nurses, practitioners became symbols of the 'social ills' of the time (Fealy, 2006, p. 15). At this time the existence of quality nurse training was questionable and hospitals for the most part were employing untrained nurses (Robins, 2000). Fealy (2006, p. 31) recounts the 1885 Dublin Hospitals Commission noting a lack of 'formal arrangements' for training, with O'Connell (2018, p. 21) adding that access to training was 'erratic' at best. However, the increasing number of hospitals created an arena for the class structures to mix (Fealy, 2006, p. 20) and, over time, created a setting for a discussion on what a nurse should and should not be, and ultimately brought order to their training. 
In the public arena a shifting of the social narrative also occurred, moving 'nurses of poor station' to 'lady nurses' (Fealy, 2006, pp. 6182). A recrafting of the nurses' identity had begun, moving them from symbols of the ills of society to almost angels of mercy status. Through the introduction of formal training within hospitals, the formation of the professions we have today was seeded and the concept of the nurse as an expert practitioner began. The identity of the nurse was being slowly moulded into a formalised, structured profession within Irish society. Society was seeing this changing ideology through experiences with the professions and the symbols of the professions - symbols such as changing uniforms from the Victorian-era dark linen with white lace to the new hygienic white/blue uniforms that were evolving at this time (Fahey, 1998; Robins, 2000). Taking a sociocultural perspective, the authors suggest society was beginning to experience a new practice environment within the hospitals, one that was reframing the focus on hygiene and cleanliness, with the role of the nurse at the centre of this new experience.

In 1902 the British Parliament enacted the Midwives Act 1902 (England) (Stevens, 2002). This, along with the rising international suffragist movement's demand for wider social change for women, gave momentum to calls for registration of the nursing and midwifery professions in Ireland and the UK. For the professions, the focus was on securing state registration and the standardisation of training (Fealy, 2006, p. 83). While public experience and interaction with practitioners may not have been the illegality, immorality and scandal', as described to the 1904 British Government Select Committee by some, there was disparity in experiences and some professionals 'had serious shortcomings' (Robins, 2000, p. 13). In 1904 the Irish Nurses Association and the Irish Matrons Association formed to push for the registration of the profession in Ireland (Fealy, 2006, p. 85). Fealy (2006) and McMahon (2005) both recount the evidence presented to the House of Commons Select Committee urging for state registration. Concerns raised include individuals misrepresenting themselves as trained professionals, poor quality of care, the general low character of some practitioners, along with the need to assure the public of the reputability of the nurse. However, not everyone felt registration was the answer or in the best interest of the profession and society. Glasper \& Carpenter (2019) claimed Florence Nightingale (to many the founder of modern nursing) opposed UK registration, fearing working-class women with minimal education might be excluded from practice. Nightingale was cautious of wider 
social implications of the proposed legislation, how it might shape the profession and the communities within which they worked; in particular, how social class and standing within the community might influence the professions' future and those who could practise.

In 1909, responding to political pressure, the UK government created a Central Committee for the State Registration of Nurses. However, wider sociocultural political issues intervened by way of the Great War (1914-18) and the 1916 Irish uprising. These all but stopped the professional legislative process until 1917. In line with the prevailing ideology of independence and Irish nationalism, and in a direct attempt to assert independence from the British College of Nursing, the Irish Nursing Board was established. It aimed to form a register, improve training and attain self-regulation for Irish nursing (Fealy, 2006, p. 88). In 1919, after almost a decade of bills being submitted to UK Parliament, the passing of the Nursing Registration Act 1919, excluding Ireland, caused a delegation from the Irish Nursing Board to travel to London to lobby for their registration.

This period of professional pre-regulatory activity focusing on the need for registration and professional education culminated in the passing of the 1918 Midwives (Ireland) Act and the Nurses' Registration (Ireland) Act of 1919 by the UK Parliament. Two separate professions were created within law, as were two regulatory bodies: the nine-member (including three midwives) Central Midwives Board and the fifteen-member (including a nine-nurse professional majority board) General Nursing Council for Ireland. The creation of these bodies coincided with wider social and structural changes in Irish healthcare, with an increasing number of hospitals and a shifting of the public narrative around healthcare (Fahey, 1998; Fealy, 2006; Geary, 2018). Upon enactment, each regulator set about creating their registers, and evolving training to protect the image of the profession within the public realm. The embedding of a new ideology within professional practice had begun. It was the start of a new social context within which nurses and midwives would practise for many years to come.

Recounting these foundations of regulation of the modern professions through a sociocultural lens uncovers how wider renegotiated understandings of gender roles, social class, political agenda and religion all influenced the shaping of nurses' and midwives' identity from their outset. To attain professional recognition, issues of class, gender, politics, cultural representations and behaviours had all to be confronted and reimagined, and a new 
ideology embedded within society. From the outset, these professions were fighting for recognition and rights to practise, ultimately taking decades to realise. As Abel-Smith (1991, cited in Fealy, 2006, p. 98) recounted, attempts to get state recognition was a 'battle for status', played out in a field of snobbery and feminism, a battle some would argue continues to play out to this day. By 1918/19, society had finally become aware and receptive of the role of women in medicine and in society. The roles and identities of nurses and midwives were recrafted as educationally grounded professions that were legislatively recognised within Irish society for the first time. The journey as two regulated professions with defined roles and expectations from society had begun.

\section{Rationalisation in the post-war era: The 1950 Act}

While subsequent legislative updates occurred in the intervening years, the ideological focus on rationalisation in the post-World War II era and a recently enacted 1937 Irish Constitution comprise the next regulatory pivotal point explored. With the establishment of Ireland's first Department of Health in 1947 and the publication of the Health Act 1953, the focus shifted to provision of a public healthcare system by the state (McDaid et al., 2009). Thus far, healthcare was the individual's own concern and at their own cost. At this time many of the hospitals that had evolved through the philanthropic approaches mentioned earlier were recognised in legislation. In drafting the 1953 Health Act, the Irish state communicated a desire to centralise, rationalise and control its growing healthcare workforce, of which nursing and midwifery constituted a considerable portion (Robins, 2000). The prevailing post-war ideology at this time was driven by a concern to integrate and streamline public services. However, politics, class, gender and a multitude of other factors remained at the centre of Irish ideology as a new regulatory frame was being crafted for nursing and midwifery.

Taking a Foucauldian perspective, the Irish state was in essence embedding within its regulatory frame concepts of governmentality, surveillance and control so as to manage its considerable resource (Foucault, 1991). A frame where midwifery was becoming a subprofession of nursing in all but name, with nursing in turn a subordinate profession of medicine, needing supervision and surveillance. Towards the end of the 1940 s, proposals to create a new single board to regulate both the nursing and midwifery professions 
and effectively reshape the identity of the midwife were put in place by the Irish government (Matthews, 2018). For nursing, the government focus was to unify the nursing and midwifery professions so as to deliver flexible services required by a changing Irish Health Service (Fealy, 2019). The professions do not reflect on this period in a positive light. Indeed, at the time reservations by the professions were clearly stated, and in particular fears that too much power was being invested in the minister and the evolving new Department of Health rather than in the professions themselves (Fealy, 2006, p. 121).

The 1950 Nurses Act created An Bord Altranais (the Nursing Board), a twenty-three-person regulatory body with ten elected nurses (Ryan, 2019). It also created an eight-member Midwifery SubCommittee. Interestingly, in directing the composition of the midwifery committee, the 1950 Act specified that membership was to include 'nurses from the Board who had to be a midwife' (Hughes, 2018). Clearly, such language places the nurse at the centre of regulatory activity; being a midwife was a secondary function. To the midwifery profession, the state's attempt to change the title 'midwife' to 'maternity nurse' threatened the profession's existence (O'Connell, 2018, p. 22). They feared midwifery would become a subsection of the nursing profession. While ultimately the term midwife remained, the Central Midwifery Board was subsumed within the Nursing Board, as was its register.

In the $1950 \mathrm{~s}$, at a professional practice level, nursing was still considered a subordinate profession and 'dirty work' (McNamara, 2005 , p. 63) due to the nature of the skills and activities they were required to engage in: hygiene, wound care and having close contact with their patients. While arguments to establish university links for training were afoot to formalise and raise the level of skills and training, degree status would not occur until the early 2000s. McNamara (2005) suggests society was again framing the role of the professions within wider views on class, sex and gender roles. Nursing and midwifery training at this time was hospital based, with the majority of students 'living in' (Ryan, 2000). This allowed once again for the reshaping of the image and identity of the professions. Cultural 'reifications' (Wenger, 1998) of the professions such as uniforms, inspections, curfews, rules and regulations became the order of the day and symbols of the profession and professionalism. Hierarchy and control, where 'Matron reigned supreme', was the norm (Kelleher \& Musgrave, 2000, p. 187). Engagement with these artefacts of the profession enabled the individual to become, and be clearly 
recognised as, a professional nurse/midwife through their appearance and behaviour. It also reinforced social norms concerning power relationships, surveillance and 'governmentality' (Foucault, 1991). One unplanned outcome recorded by Ryan (2000, p. 85) of the socialisation impact of 'living in' was that some retiring nurses were 'institutionalised' and inexperienced in managing normal household affairs - so much so that they were not capable of living outside the institutional setting and had to retire to nursing homes. If we are to believe Ryan, for some at least, becoming a nurse disabled some of their other social and cultural skills. 'Living in' was shaping nurses' professional identity and impacting their personal identity.

The regulator's role at this time was no longer concerned with just registration but also approval of training and accommodation for trainees, having become an agent of the state for such functions. As noted by Ryan (2019), the political narrative at the time stressed a need for properly trained nursing staff to populate the changing and growing Irish health service of the future. Nurses were after all accounting for 60 to 80 per cent of hospital staff (Ryan, 2019). Once enacted, the 1950 Act enabled a new single board to issue rules, regulations and other policy documents which would go on to shape the expectations and identity of the professionals and their training for the decades to come. Of note from this regulatory pivot point was an altering of the professional identity of midwives. As noted by O'Connell (2018), in 194883 per cent of midwifery applicants were direct entrants, while just four years after the 1950 Act all but a handful of midwifery applicants had a prior nursing qualification. The 1950 Act, although retaining the term midwife, would dramatically alter their training and professional identity, which had all but been lost within the growing hospital structures. Midwifery was being shaped by the sociocultural and ideological norms of 1950s Ireland as a subsection of the nursing profession. Handywomen, who were once community based and respected individuals within their locality, were evolving into an institutionalised profession within the hospital setting.

\section{Embedding self-regulation: The 1985 Act}

Moving forward to the early 1980s, a new ideology on regulation was coming to the fore, the concept of professional self-regulation. With its roots in the concept of clinical autonomy, self-regulation had dominated UK healthcare since 1858. Davies (2004) suggests it gives a profession the legal right to create a register and conditions for 
registration. Taking a Foucauldian perspective, a regulatory frame based on a clinical autonomy model, acknowledges that the medical practitioner has the knowledge, expertise and power to make decisions and take actions without requiring external surveillance. Selfregulation results from negotiated boundaries and expectations between society and the professions, and becomes symbolic of a country's 'division of labour', what they value and what they do not (Evetts \& Dingwall, 2002). It is an expression of how the profession is viewed and trusted within society. Over time, as the self-regulation model evolved, professional identities grounded in concepts of being a competent and fit practitioner accountable to one's own profession came to the fore.

In 1975 the Irish government established a working party on general nursing. It published its report to government five years later (Department of Health, 1980). The report made recommendations on nurses and midwives' education, the scope of professional practice and the role of the regulator.

The report proposed a variety of recommendations concerning the regulation of midwifery and nursing. Of interest again is the concept of gendered roles within the report. By now there was an increasing number of males working in the professions; however, the report makes clear that nursing remained, even in 1980, "predominantly a female profession' (Department of Health, 1980, p. 6). It recommended the retention of the midwives' committee established under the 1950 Act, also making it clear that entry into midwifery would only be open to Nurses (pp. 51-2). Importantly, the report notes that while the 1950 Act empowered An Bord Altranais (the Board) to 'remove' individuals from the register, the Board did not actively use such powers due to doubts about constitutionality. The report also proposed the legislation for a professional majority fitnessto-practise committee with a range of powers to monitor and control the profession, and the need to formalise the 'professional selfregulation' paradigm that was already operating in other jurisdictions, including the UK. In addition, the report recommended the establishment of a twenty-seven-member board, with 63 per cent of its membership elected directly by the professions. In total just 10 of the 151 pages in the report referred to the regulatory function. The 1980 report led to the development of the Nurses Bill 1984 and ultimately, with minor alterations, the Nurses Act 1985.

The Board, in the years that followed, drafted rules and regulations around professional practice, education and other issues that fed into 
the fitness-to-practise regime. Fitness-to-practise committees and panels were established, as were formal processes for hearing cases and issuing sanctions - a regime that still influences to this day, as the current board has a small number of open cases under the 1985 Act. The reframing of the midwife's identity was now enshrined in legislation as a 'branch of nursing' (O'Connell, 2018, p. 22). This caused great concern for professional midwives as it challenged their autonomous practice. The paradigm of professional self-regulation, 'which views the profession itself as the ultimate arbitrator of the profession's failings', was enshrined within the Act (Bevan, 2008, p. 87).

The interplay of wider social constructs of identity and professionalism was challenging the professions to respond and evolve. Changes to the Act with regards to self-regulation could be viewed as government empowering the profession to control its future. Society was trusting the profession to self-regulate and to control its professionals. However, as also noted by Bevan (2008), changes to this self-regulation model would inevitably have to occur as healthcare had to become increasingly accountable and competitive in an evolving market as the century came to a close.

\section{Scandals and calls for public accountability: The 2011 Act}

As noted by Bevan (2008), towards the end of the twentieth century, self-regulation was no longer in vogue. The disquiet with selfregulation started in the financial and auditing sectors. O'Regan \& Killian (2014) and Canning \& O'Dwyer (2013) discuss the issues driving change in Ireland's regulatory context. In healthcare an array of international and national scandals resulted in political and public demands for a transparent and public-focused regulatory model to evolve.

Healthcare also faced its own scandals and increasing calls for accountability and transparency. The Public Inquiry into Children's Heart Surgery at the Bristol Royal Infirmary (Department of Health (UK), 2001) and the Shipman Inquiry (Department of Health (UK), 2002-5) are two notable UK examples. The Lourdes Hospital Inquiry (Irish Nurses Organisation, 2006), A Review of the Deaths at Leas Cross Nursing Home 2002-2005 (O'Neill, 2006) and the Tallaght Hospital Review (Health Service Executive, 2010) being just a few local Irish examples. 
As well as wider structural and governance failings, these reports paint a picture of healthcare professionals with what Donoghue (2009, p. 64) suggest many perceive as an 'untouchable dominance'. Bullying, intimidation, incompetence and a reluctance to change can be seen in various forms within some of these reports. Indeed, McCarthy et al. (2008) suggest that so too can issues around power, influence, gender, hierarchy and prejudices. For the most part the nursing and midwifery professional body welcomed the findings, conclusions and recommendations of both the Leas Cross and Lourdes Hospital inquiries (Irish Nurses Organisation, 2005, 2006). Reports and investigations continue to be commissioned by the Irish government and regulators. More recent reports include those commonly referred to as the 'Portlaoise Report' (Health Information and Quality Authority, 2015) and the 'Savita Halappanavar Report' (Health Information and Quality Authority, 2013).

Arising from many of these reports was a wider social awareness of the healthcare context, which in turn led to a call for regulatory reform with a focus on the public interest role that ultimately led to the concept of a lay majority board (O'Regan \& Killian, 2014). The profession had reservations about these changes and clearly highlighted their concerns. In particular, the Irish Nurses Organisation (2008a) circular to nurses highlighted a lack of evidence to suggest existing systems were failing. Their consultation submission in the run up to the 2011 Act to the Department of Health and Children claimed 'inadequate' board composition and that the proposed reduction of professionals on the board would result in 'relevant expertise and knowledge' being lost (Irish Nurses Organisation, 2008b, p. 2). It further called the proposed composition 'fundamentally flawed' (p. 6).

A comparison of the 1985 and 2011 Acts enables an understanding of the professional body's concerns. Board composition under the 1985 and 2011 Acts shows a shift in directly elected professionals from 59 per cent in 1985 to 35 per cent in 2011. A visible shift in boardroom power and dynamics was being played out. Wider sociocultural norms at this time were reframed around an ideology of public accountability and transparency. These were shaping the professions, the way in which the public engaged with them and the body that regulates them. The 2011 Act could be viewed as being at the opposite end of a dichotomy of the previous self-regulating model. Using a sociocultural lens to reflect now on the 2011 Act and its drive to create a new regulatory frame, the professions' concern were at least understandable, as echoes of the power struggles of the early formation of the professions a century earlier were again evident. 
Despite concerns raised by the profession that the need for change had not been justified, the government passed the 2011 Nurses and Midwives Act, enabling a non-professional majority. This new regulator brought what Cornforth (2004) and Doyle et al. (2021) term a 'stakeholder' perspective to the professional regulatory boardroom. The current Board, although a non-regulated professional majority, is populated with representation of the professions, employers, educators, wider healthcare partners and the public. Importantly for practitioners, the 2011 Act also signalled the return to the two distinct professions of nursing and midwifery (O'Connell, 2018, p. 23). This is clearly cited in the Act and symbolically reflected in the title of the statute (the Nurses and Midwives Act 2011) and within the regulator's name (Nursing and Midwifery Board of Ireland).

In the twenty-first century the professions continue to face challenges not only within the boardroom but in the wider social context. In moving from a vocational training model to a four-year degree programme, the professions had to again engage in public debate and a reshaping of the identity of the professions (McNamara, 2008). Battling widely held and popular stereotypes, with nursing ranging from a 'sacred' to a 'profane' profession and nurses from 'angels' to 'whores', the professions responded by grounding themselves in academic and scientific paradigms (McNamara, 2008, p. 462). Securing degree status meant the profession would finally be grounded in the scientific and professional paradigm. Some, however, lamented the loss of the concept of the core vocation within the nurse's identity (Wood, 2020).

The professions have and will continue to evolve as they embark into the second centenary of professional regulation. This evolution is likely to be with regards to scope of practice, but also with regards to areas of specialism and to academic routes of entry and progression. This is already to be seen within the wider sociocultural frame from the exponential growth in registered advance nurse/midwife practitioners since establishment in 2001 (Kerr \& MacAskill, 2020), and through the Department of Health's 2019 policy document (Department of Health, 2019).

\section{Discussion}

Taking a wider sociocultural view on professional regulation of the nursing and midwifery professions in Ireland enables an understanding of the current regulatory form within its historical 
context. By exploring changing ideology, various driving and resisting forces beyond the professions themselves are uncovered that have influenced the shaping of the professions we see today and their regulation over the last century. This in turn leads to the questioning and unpacking of prevailing ideologies to understand how they have shaped professional practice for the professions. Professional regulatory frames are fluid and can be seen as an attempt to balance wider societal norms and expectations with the profession's expectations of respect, recognition and autonomy of practice.

From the outset, for Ireland's nurses and midwives, factors grounded in social and cultural understandings of concepts such as gender, social class, religion, politics and professionalism have been among the driving factors that have shaped the professions, their practice and their regulation. From early beginnings, the handprint of these wider influences can be seen. By painting a picture of unregulated professionals engaged in dirty work and of nursing and midwifery as professions symbolic of the social ills with whom they worked, and by aligning with wider political direction, a desire for regulation was created in early-1900s Ireland. This pivotal point became a driver for professional change as the profession availed of wider social and political factors, including attitudes towards women and nationalism, to reconstruct the social narrative around the professions. Ultimately, this led to the enactment of the 1918 midwifery and 1919 nursing Acts, creating two distinct professions and regulators.

By the enactment of the 1950 Act, wider social and political desires for healthcare change, as well as rationalisation and development of a national public health system, were driving the desire for change in the professions and their regulation. The emphasis was on a governmental narrative around efficiency and a public need for staff competently trained to meet evolving hospital system requirements. On this occasion, rather than the professions taking the lead, government became a driving force. By combining existing regulators into one, the Irish government again reframed the narrative around the professions and achieved its desired outcome of greater centralised control of one of its largest public workforces. In doing so, they also altered the professions. Indeed, as recounted earlier, some would argue they commenced a deconstruction of the profession of midwifery.

The rise in the fitness-to-practise agenda grounded in a selfregulation paradigm was a key driver for the 1985 Act. Wider social 
demands for accountability were being balanced against concepts of clinical autonomy and self-regulation. Once again, the professions themselves took a leading role in creating the new narrative, drawing in wider social and political factors to support the argument. The narrative now focused on portraying the professions as being responsible and accountable and one that can be trusted to selfregulate. Resulting from the 1985 Act, almost 60 per cent of the regulator was directly elected by the profession, its highest-ever representation.

As the century turned, the 1985 self-regulation model fell out of favour due to healthcare governance scandals. The narrative around the professions was being recrafted, this time in the light of a wider mistrust of clinical autonomy. The 2011 Act attempted to address this and to assure the public by, amongst other things, reducing directly represented professionals to just 35 per cent of board composition. Despite strong representation from the professions who questioned the need for change, the wider social agenda with an increasing mistrust in public services led to the 2011 Act being implemented.

Recounting the history of regulation for these professions, we see that regulatory change in Ireland for these professions has been evolutionary in response to wider stimulus. Indeed, the next incremental change has recently been implemented by the Oireachtas (the Irish government) in the Regulated Professions (Health and Social Care) (Amendment) Act 2020. These changes focus on streamlining fitness-to-practise processes and increasing the use of the public courts system with regards to sanction and appeals within the fitness-to-practise mechanism. The professional representative body is unsurprisingly cautious of the proposed changes and the debate around regulation of the professions continues (Mathews, 2019).

As this paper was being written, Irish healthcare faced two new wider issues: management of its ongoing response to the Covid-19 pandemic and the May 2021 cyberattack on its information technology systems. Both these factors dramatically influenced service provision and healthcare workers' ability to provide care. Bowers (2021) refers to it as 'a horrible convergence of crises'. The impact of the Covid-19 pandemic on health professionals is far-reaching. It is influencing not only service provision but also the delivery of education of new professionals (Daodu et al., 2020; Quinn et al., 2020; Rose, 2020). The battle against what Bowers (2021) terms the 'two viruses' is still in train; however, a new narrative around healthcare work is evolving. 
Nurses and midwives are now characterised as frontline defenders in the fight against Covid-19, striking up imagery and narratives of wartime (Kenny, 2020). How this will evolve as a wider narrative is yet to be seen, as is the impact this may have on how nursing, midwifery and other health professionals will be regulated in the future.

Other social and cultural factors at play are also worthy of consideration as to how they may influence future regulatory frames. For example:

- There is what appears to be an increasing public distrust of politics and a rising populist agenda (Citrin \& Stoker, 2018). Such lack of trust in the political and related civil and public services arena will need monitoring for potential impact on the regulatory frame.

- There is the ever-changing relationship between the UK and Ireland and what will stem from Brexit, which has had little discussion while Covid has taken centre stage (Taylor, 2021). For authors such as Roche (2019) and Peel (2019), the concept of Brexit itself is enshrined in a historical pattern and is inevitably going to shape future Anglo-Irish relationships in almost every sector of society. How this may influence professional regulation is yet to be understood.

- There is an apparent rise of a nationalist agenda and Euroscepticism within Europe that may ultimately threaten core European values such as free movement (Mason, 2020). There is also the rising phenomena of fake news, driven by social media platforms and a somewhat naive and susceptible public who unknowingly stoke the fires of other agendas by sharing such posts (Talwar et al., 2019). Any change in European structures will inevitably influence the regulatory frame of the future.

When explored through a wider sociocultural lens, what shapes the future of professional regulation can be diverse and far-reaching. Any or all of the aforementioned factors and many others not recounted have the potential to spark the next pivotal point of change for the professions' regulatory frame.

\section{Conclusion}

In accepting that wider sociocultural factors influence the direction of regulation, some lessons and conclusions can be surmised. Firstly, we can conclude that regulation, professional practice and professional 
education are inextricably linked. Changes of views in one can in time impact the other. Secondly, it is prudent to observe our current society so as to identify possible ideological shifts and how any changes in ideology might impact regulation of the professions in the coming years. Thirdly, there are some noticeable trends observable in the media that may challenge and impact the direction of regulation and in turn professional practice. Finally, we can conclude that the regulatory frame will again change in the coming years, influenced by an array of diverse factors that are currently shaping and altering ideology within Irish society.

When viewed from a sociocultural perspective the shaping of the professions' identity and their regulation will continue to develop through engagement between the professions, the public and the regulator. What evolves in the coming decades is likely to be a negotiated compromise as new societal and professional identities are again renegotiated and reframed.

\section{References}

Bevan, G. (2008). Changing paradigms of governance and regulation of quality of healthcare in England. Health, Risk and Society, 10 (1), 85-101.

Bowers, F. (2021). The pandemic and cyber attack, a tale of two viruses. Retrieved from https://www.rte.ie/news/2021/0522/1223126-fergal-bowerscoronavirus/ [22 May 2021].

Breathnach, C. (2016). Handywomen and birthing in rural Ireland, 1851-1955. Gender \& History, 28 (1), 34-56.

Canning, M., \& O'Dwyer, B. (2013). The dynamics of a regulatory space realignment: Strategic responses in a local context. Accounting, Organizations and Society, 38, 169-94.

Citrin, J., \& Stoker, L. (2018). Political trust in a cynical age. Annual Review of Political Science, 21, 49-70.

Clarke, M. (2015). Education of girls in Ireland: Secondary and vocational curricular provisions 1930-1960. History of Education, 45 (1), 79-102.

Cornforth, C. (2004). The governance of cooperatives and mutual associations: A paradox perspective. Annals of Public and Cooperative Economics, 75 (1), 11-32.

Daodu, O., Panda. N., Lopushinsky, S., Varghese Jr, T. K., \& Brindle, M. (2020). COVID-19 - Considerations and implications for surgical learners. Annals of Surgery, 272 (1), 22-3.

Davies, C. (2004). Regulating the health care workforce: Next steps for research. Journal for Health Services Research and Policy, 9 (1), 55-61.

Department of Health. (1980). Working party on general nursing. Dublin: Government Publications. 
Department of Health. (2019). Policy on the development of graduate to advanced nursing and midwifery practice. Dublin: Department of Health.

Department of Health (UK). (2001). The report of the public inquiry into children's heart surgery at the Bristol Royal Infirmary 1984-1995: Learning from Bristol (Cm 5207(II)). London: Department of Health (UK).

Department of Health (UK). (2002-5). The Shipman Inquiry. London: Department of Health (UK).

Donoghue, E. (2009). Professional self-regulation and the public interest: $A$ question of confidence. Belfast: Queen's University.

Doyle, D., Murphy, D., \& Watson, D. (2021). Corporate governance: An organisational attribute or an academic exercise? The Market: International Journal of Business, 2, 3-12.

Evans, L. (2008). Professionalism, professionality and the development of education professionals. British Journal of Educational Studies, 56 (1), 20-38.

Evetts, J., \& Dingwall, R. (2002). Professional occupations in the UK and Europe: Legitimation and governmentality. International Review of Sociology, 12 (2), 9-17.

Fahey, T. (1998). The Catholic Church and social policy. In S. R. B. Healy (Ed.), Social policy in Ireland. Principles, practice and problems (pp. 143-63). Dublin: Oaktree Press.

Fealy, G. (2006). A history of apprenticeship nurse training in Ireland. Abingdon: Routledge.

Fealy, G. (2019). A very great advantage: State regulation of nursing and the general nursing council for Ireland, 1920-1950. Retrieved from https://www.nmbi.ie/News/News/100-Years-of-Nursing-RegulationConference-(1) [15 January 2020].

Fealy, G., \& O’Doherty, M. (2005). Lessons from history. In G. M. Fealy (Ed.), Care to remember: Nursing and Midwifery in Ireland (pp. 11-27). Cork: Mercier Press.

Fletcher, R. (2001). Post-colonial fragments: Representations of abortion in Irish law and politics. Journal of Law and Society, 28 (4), 568-89.

Foucault, M. (1966). The order of things: An archaeology of the human sciences (Taylor and Francis e-Library 2005 English translation ed.) Paris: Éditions Gallimard.

Foucault, M. (1991). Governmentality. In G. Burchell, C. Gordon \& P. Miller (Eds), The Foucault effect: Studies in governmentality. Chicago: University of Chicago Press.

Geary, L. (2018). From voluntary hospitals to voluntary health insurance: A history of Irish healthcare from the early-eighteenth to the midtwentieth century. In Health Insurance Authority, The Irish healthcare system: An historical and comparative review (pp. 9-28). Dublin: Health Insurance Authority.

Glasper, A., \& Carpenter, D. (2019). Celebrating 100 years of nurse regulation. British Journal of Nursing, 28 (22), 1490-1. 
Gray, B., \& Ryan, L. (1998). The politics of Irish identity and the interconnections between feminism, nationhood, and colonialism. In R. Pierson (Ed.), Nation, empire, colony: Historicizing gender and race. (pp. 121-38.). Bloomington: Indiana University Press.

Health Information and Quality Authority. (2013). Investigation into the safety, quality and standards of services provided by the Health Service Executive to patients, including pregnant women, at risk of clinical deterioration, including those provided in University Hospital Galway, and as reflected in the care and treatment provided to Savita Halappanavar. Dublin: Health Information and Quality Authority.

Health Information and Quality Authority. (2015). Report of the investigation into the safety, quality and standards of services provided by the Health Service Executive to patients in the Midland Regional Hospital, Portlaoise. Dublin: Health Information and Quality Authority.

Health Service Executive. (2010). Tallaght Hospital review: Report of the review of radiology reporting and the management of GP referral letters at Adelaide and Meath Hospital (Dublin), incorporating the National Children's Hospital (AMNCH) [Tallaght Hospital]. Dublin: Health Service Executive.

Hughes, B. (2018). Midwifery practice in Ireland the last 100 years. Dublin: Nursing and Midwifery Board of Ireland.

Irish Nurses Organisation. (2005). INO condemns conditions highlighted on RTE's Prime Time Investigation programme on Leas Cross Nursing Home. Dublin: Irish Nurses Organisation.

Irish Nurses Organisation. (2006). Lourdes Hospital Inquiry (report of Judge Maureen Harding S.C.) statement by Irish Nurses Organisation. Dublin: Irish Nurses Organisation.

Irish Nurses Organisation. (2008a). Clarity and quality key to INO submission on new nurses and midwives bill. World of Irish Nursing, 16 (3).

Irish Nurses Organisation. (2008b). Submission to the Department of Health and Children on the draft heads of the proposed nurses and midwives bill. Dublin: Irish Nurses and Midwives Organisation.

Kelleher, A., \& Musgrave, E. (2000). Sick children's nursing. In J. Robins (Ed.), Nursing and midwifery in Ireland in the twentieth century: Fifty years of an Bord Altranais (the Nursing Board) 1950-2000. Dublin: An Bord Altranais.

Kenny, C. (2020). 'This is war': Irish health workers on their Covid-19 crises. Retrieved from https://www.irishtimes.com/life-and-style/healthfamily/this-is-war-irish-health-workers-on-their-covid-19-crises-1.4218979 [7 February 2021].

Kerr, L., \& MacAskill, A. (2020). The journey from nurse to advanced nurse practitioner: Applying concepts of role-transitioning.. British Journal of Nursing, 29 (10), 561-5.

Khalili, H., Hall, J., \& DeLuca, S. (2014). Historical analysis of professionalism in western societies: Implications from inter-professional education and collaborative practice. Journal of Interprofessional Care, 22 (2), 92-7. 
Lave, J. (1998). Cognition in practice: Mind, mathematics and culture in everyday life (digital ed.) Cambridge: Cambridge University Press.

Lave, J., \& Wenger, E. (1991). Situated learning; Legitimate peripheral participation (20th ed.) Cambridge: Cambridge University Press.

Lougheed, K. (2018). 'After the manner of the Irish schools': The influence of Irish national education in the British Empire. Journal of Historical Geography, 60, 1-10.

Mason, A. (2020). Europe's future: The impact of Covid-19 on populism. Paris: International Development Research Network.

Mathews, E. (2019). Regulation reform. World of Irish Nursing, 27 (6), 26-7.

Matthews, A. (2018). The politics of midwifery regulation in Ireland: The background to the abolition of the Central Midwifery Board for Ireland. Dublin: Nursing and Midwifery Board of Ireland.

McCarthy, J., Murphy, S., \& Loughrey, M. (2008). Gender and power: The Irish hysterectomy scandal. Nursing Ethics, 15 (5), 643-55.

McDaid, D., Wiley, M., Maresso, A., \& Mossialos, E. (2009). Ireland: Health system review. Health systems in transition. Copenhagen: European Observatory on Health Systems and Policies.

McMahon, A. (2005). Regulating midwives: The role of the Royal College of Physicians of Ireland. In G. Fealy (Ed.), Care to remember: Nursing and midwifery in Ireland (pp. 158-71). Cork: Mercier Press.

McNamara, M. (2005). 'Dr Nightingale, I presume?' Irish nursing education enters the academy. In G. Fealy (Ed.), Care to remember: Nursing and midwifery in Ireland (pp. 54-68). Cork: Mercier Press.

McNamara, M. (2008). Of bedpans and ivory towers? Nurse academics' identity and the sacred and profane: A Bernsteinian analysis and discussion paper. International Journal of Nursing Studies, 45, 458-70.

Mohr, T. (2010). British imperial statutes and Irish law: Imperial statutes passed before the creation of the Irish Free State. The Journal of Legal History, 31 (3), 299-321.

O’Connell, R. (2018). Midwifery 1918-2018: Coming full circle. World of Irish Nursing, 26 (10), 21-3.

Ó Drisceoil, M. (2020). Catholicism \& the judiciary in Ireland, 1922-1960. Irish Judicial Studies Journal, 4 (1).

O'Neill, D. (2006). A review of the deaths at Leas Cross Nursing Home 20022005. Dublin: Department of Health.

O'Regan, P., \& Killian, S. (2014). Professionals who understand: Expertise, public interest and societal risk governance. Accounting, Organisations and Society, 39, 615-31.

Peel, M. (2019). Brexit is blinding Britain to both its history and its present. Retrieved from https://www.irishtimes.com/opinion/brexit-is-blindingbritain-to-both-its-history-and-its-present-1.4034275 [12 January 2020].

Professional Standards Authority. (2016). Professional identities and regulation: A literature review. Retrieved from https://www.professionalstandards. org.uk/publications/detail/professional-identities-and-regulation-aliterature-review [18 June 2020]. 
Quinn, B., Field, J., Gorter, R., Akota, I., Manzanares, M.-C., Paganelli, C., ... Tubert-Jeannin, S. (2020). COVID 19: The immediate response of European academic dental institutions and future implications for dental education. European Journal of Dental Education, 24 (4), 811-14.

Robins, J. (2000). Nursing and midwifery in Ireland in the twentieth century: Fifty years of An Bord Altranais (The Nursing Board) 1950-2000. Dublin: An Bord Altranais.

Roche, B. (2019). British policy on Brexit is part of an historical pattern, conference told. Retrieved from https://www.irishtimes.com/news/ireland/ irish-news/british-policy-on-brexit-is-part-of-an-historical-patternconference-told-1.3983008 [14 January 2020].

Rogoff, B. (2008). Observing sociocultural activity on three planes: Participatory appropriation, guided participation, and apprenticeship. In K. Hall, P. Murphy \& J. Soler (Eds), Pedagogy and practice: Culture and identities (pp. 58-74). Milton Keynes: Open University Press.

Rose, S. (2020). Medical student education in the time of COVID-19. JAMA, 323 (21), 2131-2.

Ryan, A. (2000). General nursing. In J. Robins (Ed.), Nursing and midwifery in Ireland in the twentieth century: Fifty years of An Bord Altranais (The Nursing Board) 1950-2000 (pp. 77-99). Dublin: An Bord Altranais.

Ryan, A. (2019). Nursing regulation for the last 100 years: 1950 to date. Retrieved from https://www.nmbi.ie/News/News/100-Years-of-NursingRegulation-Conference-(1) [15 January 2020].

Sheehan, A., Berkery, E., \& Lichrou, M. (2017). Changing role of women in the Irish society: An overview of the female consumer. Irish Journal of Management, 36 (3), 162-71.

Stevens, R. (2002). The Midwives Act 1902: An historical landmark. RCM Midwives, 5 (11), 370-1.

Talwar, S., Dhir, A., Kaur, P., Zafar, N., \& Alrasheedy, M. (2019). Why do people share fake news? Associations between the dark side of social media use and fake news sharing behaviour. Journal of Retailing and Consumer Services, 51, 72-82.

Taylor, C. (2021). The Brexit squeeze on the Irish economy is only just starting. Retrieved from https://www.irishtimes.com/business/economy/the-brexitsqueeze-on-the-irish-economy-is-only-just-starting-1.4576886? $\operatorname{mode}=$ sample $\&$ auth-failed $=1 \&$ pw-origin $=$ https $\% 3 \mathrm{~A} \% 2 \mathrm{~F} \% 2 \mathrm{Fwww}$. irishtimes.com $\% 2$ Fbusiness $\% 2$ Feconomy $\% 2$ Fthe-brexit-squeeze-on-theirish-economy-is-only [27 May 2021].

Vygotsky, L. (1978). Mind in society: The development of higher psychological processes. Cambridge: Harvard University Press.

Walsh, R., \& Fox-O’Mahony, L. (2018). Land law, property ideologies and the British-Irish relationship. Common Law World Review, 47 (1), 7-34.

Wenger, E. (1998). Communities of practice. New York: Cambridge University Press. 
Wertsch, J. (2008). From social interaction to higher psychological processes: A clarification and application of Vygotsky's theory. Human Development, 51, 66-79.

White, T. (2010). The impact of British colonialism on Irish Catholicism and national identity: Repression, reemergence, and divergence. Études Irlandaises, 35 (1), 21-37.

Wood, S. (2020). Keeping the nurse in the nurse practitioner. Advances in Nursing Science, 43 (1), 50-61. 